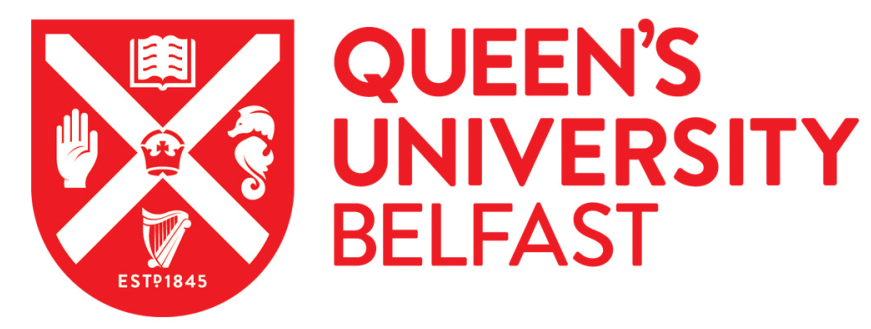

\title{
SCILLs as selective catalysts for the oxidation of aromatic alcohols
}

Podolean, I., Pavel, O. D., Manyar, H. G., Taylor, S. F. R., Ralphs, K., Goodrich, P., Pârvulescu, V. I., \& Hardacre, C. (2018). SCILLs as selective catalysts for the oxidation of aromatic alcohols. Catalysis Today. https://doi.org/10.1016/j.cattod.2018.07.014

\section{Published in: \\ Catalysis Today}

\section{Document Version:}

Peer reviewed version

Queen's University Belfast - Research Portal:

Link to publication record in Queen's University Belfast Research Portal

Publisher rights

(c) 2018 Elsevier B. V.

This work is made available online in accordance with the publisher's policies. Please refer to any applicable terms of use of the publisher.

\section{General rights}

Copyright for the publications made accessible via the Queen's University Belfast Research Portal is retained by the author(s) and / or other copyright owners and it is a condition of accessing these publications that users recognise and abide by the legal requirements associated with these rights.

Take down policy

The Research Portal is Queen's institutional repository that provides access to Queen's research output. Every effort has been made to ensure that content in the Research Portal does not infringe any person's rights, or applicable UK laws. If you discover content in the Research Portal that you believe breaches copyright or violates any law, please contact openaccess@qub.ac.uk. 


\section{Highlights}

- SCILL are efficient catalysts for the oxidation of benzyl alcohol with air.

- The IL layer modifies the selectivity to aldehyde, and nature of IL is important.

- Diluent inert $\left(\mathrm{N}_{2}, \mathrm{He}, \mathrm{Ar}\right)$ or $\left(\mathrm{CO}_{2}\right)$ reactive gases modify the $\mathrm{O}_{2}$ solubility in ILs.

- ILs enhances the structural stability of the catalyst. 
SCILLs as selective catalysts for the oxidation of aromatic alcohols

Iunia Podolean, Octavian D. Pavel, Haresh G. Manyar, S. F. Rebecca Taylor, Kathryn Ralphs, Peter Goodrich, Vasile I. Pârvulescu and Christopher Hardacre

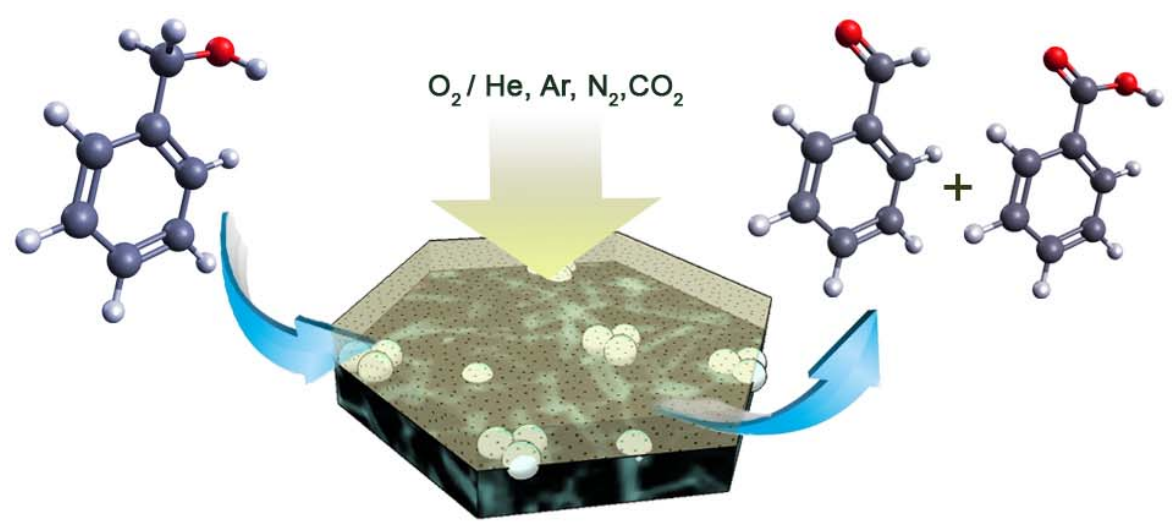

SCILL catalyst 5wt \% Pt/OMS-2/[Ionic liquid] 


\title{
SCILLs as selective catalysts for the oxidation of aromatic alcohols
}

\author{
Iunia Podolean, ${ }^{1}$ Octavian D. Pavel, ${ }^{1}$ Haresh G. Manyar, ${ }^{2}$ S. F. Rebecca Taylor, ${ }^{2,3}$ Kathryn
} Ralphs, ${ }^{2}$ Peter Goodrich, ${ }^{2}$ Vasile I. Pârvulescu ${ }^{1, *}$ and Christopher Hardacre ${ }^{2,3, *}$

${ }^{1}$ University of Bucharest, Faculty of Chemistry, Department of Organic Chemistry, Biochemistry and Catalysis, 4-12 Regina Elisabeta Av., S3, 030018 Bucharest, Romania, email: vasile.parvulescu@chimie.unibuc.ro

${ }^{2}$ Theoretical and Applied Catalysis Cluster/School of Chemistry and Chemical Engineering, Queen's University Belfast, Belfast BT9 5AG, Northern Ireland, UK

${ }^{3}$ School of Chemical Engineering and Analytical Science, The Mill-C57, The University of Manchester, Manchester, M13 9PL, e-mail: c.hardacre@manchester.ac.uk

\begin{abstract}
The cryptomelane form of manganese oxide, OMS-2, has been used a pure material as well as a $5 \mathrm{wt} \% \mathrm{Pt} / \mathrm{OMS}-2$ catalyst for the oxidation of benzyl alcohol. In addition, these catalysts have been modified with ionic liquids via a thin layer of $[\mathrm{Bmim}]\left[\mathrm{NTf}_{2}\right]$ or $[\mathrm{Bmpyr}]\left[\mathrm{NTf}_{2}\right]$. These catalysts were characterized using a series of techniques: NMR, XRD, DRIFT, Raman, BET, Dynamic Light Scattering, XPS, TEM, SEM. The Weisz-Prater criterion has also been considered to inform whether the reactions were under diffusional control. The presence of platinum on the OMS-2 surface results in the support transforming to form $\mathrm{Mn}_{3} \mathrm{O}_{4}$ during reaction. In contrast, in the presence of the ionic liquid, the catalysts exhibited an increased phase stability. Efficient oxidation of benzyl alcohol was observed with a conversion of $80 \%$ and $82 \%$ selectivity to aldehyde for $5 \mathrm{wt} \% \mathrm{Pt} / \mathrm{OMS}-2 /[\mathrm{Bmim}]\left[\mathrm{NTf}_{2}\right]$ in air. As expected an increase of the oxygen pressure led to an increase in the conversion to the detriment of aldehyde selectivity. The catalytic tests also showed an important effect on the conversion
\end{abstract}


and selectivity of benzyl alcohol as a function of the diluent gas comparing inert $\left(\mathrm{N}_{2}, \mathrm{He}, \mathrm{Ar}\right)$ or $\left(\mathrm{CO}_{2}\right)$ reactive gases. This effect was influenced by the nature of the ionic liquid present.

Keywords: SCILL, ionic liquids, Pt, OMS-2, oxidation, benzyl alcohol, benzaldehyde

\section{Introduction}

OMS-2 belong to the family of manganese oxide octahedral molecular sieves (OMS) that correspond to a synthetic cryptomelane form of manganese oxide [1] that has been extensively studied in the past decade in various catalytic reactions (selective hydrogenation of halogenated arenes [2]; total oxidation of ethyl acetate [3]; ethanol [4,5]; benzyl alcohol oxidation [6,7] and sulfide [8]), sorption and ion-exchange processes [9, 10], environmental remediation [11] and production of battery materials [12]. OMS-2 is a porous mixed-valent metal oxide $\left(\mathrm{KMn}^{4+}{ }_{7} \mathrm{Mn}^{3+} \mathrm{O}_{16} \cdot \mathrm{nH}_{2} \mathrm{O}\right)$ with a $2 \times 2$ tunnel architecture (dimensions of $4.6 \times$ $4.6 \times 6.5 \AA$ ), bearing corner and edge shared $\mathrm{MnO}_{6}$ octahedral units with $\mathrm{K}^{+}$and $\mathrm{H}_{2} \mathrm{O}$ inside the tunnel [13]. Other manganese oxide octahedral molecular sieves contain $1 \times 1$ tunnels that are too narrow to incorporate bulky cations [10], or larger $3 \times 3$ tunnels (OMS-1) which are able to accommodate larger cations like $\mathrm{Mg}^{2+}$ which, in addition, may contribute to the stabilization of the structure [14]. Its surface area [15] strongly depends on the preparation method varying in following order: solvent free $\left(155 \mathrm{~m}^{2} / \mathrm{g}\right)>$ microwave reflux $\left(148 \mathrm{~m}^{2} / \mathrm{g}\right)>$ conventional reflux $\left(96 \mathrm{~m}^{2} / \mathrm{g}\right)>$ hydrothermal $\left(44 \mathrm{~m}^{2} / \mathrm{g}\right)$. On the basis of the cations present in the structure, the different types of cryptomelanes have been classified as cryptomelane $(\mathrm{K})$, manjiroite $(\mathrm{Na})$, hollandite $(\mathrm{Ba})$, etc. [16]. In this series, potassium was reported to be able to stabilize the $2 \times 2$ tunnel structure of the cryptomelanes. Its simple exchange with protons may produce OMS-2 with acid properties [17]. Furthermore, the catalytic properties of these 
materials can easily be expanded by doping with other elements like $\mathrm{Pd}, \mathrm{Ce}, \mathrm{Co}, \mathrm{Ti}$ [18], Zr [19], Sn [20].

Ionic liquids (ILs) have received a considerable interest in the recent decades due to the very large variety of applications including electrochemistry (electrolytes in batteries, fuel cells, solar panels), chemistry (coatings, lubricants, dispersants, plasticizers, solvents, as stationary phases for HPLC), physics (as modifier refractive index, matrix for mass spectrometry), biology (embalming, biocides) [21-23] and catalysis [24]. The negligible vapor pressure, non-flammability character, Brønsted/Lewis acidity [25], the solubility of various organic, inorganic and organometallic compounds and high thermal conductivity are among the properties which made them attractive for catalysis as solvents and/or catalysts in numerous processes $[24,26]$. However, despite these advantages a number of disadvantages have been highlighted including the difficulty in isolating the product from the IL. To eliminate this problem and also to diminish the mass transfer limitations, Mehnert and coworkers [27,28] and Wasserscheid and co-workers [29,30] proposed the heterogeneization of ionic liquids as "Supported Ionic Liquid Phase (SILP)" wherein thin layers ionic liquids are deposited on solid supports. Alternatives to SILP for generating heterogeneous catalysts correspond to the anchoring of IL to the surface via a covalent bond (the SILC concept) [31] or to coating the IL on a support by physisorption (the Solid Catalyst with Ionic Liquid Layer, SCILL concept) [32-34]. To date, SCILL has been reported in selective catalytic hydrogenations including citral to citronellal [35], limonene to p-menthene [36] under supercritical $\mathrm{CO}_{2}$ conditions, propyne to propene [37] and of a 1-octene/1-octyne mixture [38]. In addition, it has been used to catalyse isomerizations [39].

The selective oxidation is an important process for manufacture of chemicals and chemical intermediates. Among these, the oxidation of benzyl alcohol to benzaldehyde is an important process due to the fact that benzaldehyde is a valuable chemical for perfumery, 
dyestuff, pharmaceutical and agro-chemical industries and also as an industrial solvent $[40,41]$. Traditionally, benzaldehyde is produced by the partial oxidation of toluene or the hydrolysis of benzylidene chloride [42] but the operating conditions of these processes are challenging and significant generation of wastewater occurs [43]. Based on this, many efforts have been made to transfer this oxidation into more environmentally friendly processes using green oxidation agents and heterogeneous catalyst systems [44-47]. Among these, the use of OMS-2 has been examined [48].

The aim of this study is to examine the influence of SCILL-type catalysts based on OMS-2 for the selective oxidation of benzyl alcohol. With this aim, we report, herein, the oxidation of benzyl alcohol with molecular oxygen or air, as cheap and friendly environmental oxidizing reagents, over IL modified and unmodified OMS-2 and 5wt $\%$ $\mathrm{Pt} / \mathrm{OMS}-2$ catalysts using $[\mathrm{Bmim}]\left[\mathrm{NTf}_{2}\right]$ and $[\mathrm{Bmpyr}]\left[\mathrm{NTf}_{2}\right]$. The selection of the two ILs considered: $i$ ) the very high stability of the $\mathrm{NTf}_{2}$ anion in water under oxidative conditions, and ii) to investigation of the effect of the nature of the cation (i.e. one IL with two $\mathrm{N}$ atoms in a five atoms cycle, and the other with one $\mathrm{N}$ atom in a six atoms cycle). Both ILs are immiscible with water. The effect of the gas phase composition has also been evaluated using $\mathrm{O}_{2}$ mixtures with $\mathrm{N}_{2}, \mathrm{He}, \mathrm{Ar}$ and $\mathrm{CO}_{2}$.

\section{Experimental}

\subsection{Preparation of the catalysts}

OMS-2 was synthesized using the sol-gel method following the procedure reported by Duan et al. [49]. 5wt\% Pt/OMS-2 was prepared by incipient wetness impregnation using a platinum nitrate solution (assay 15.14\%, Johnson-Matthey, UK), as the platinum precursor. After impregnation, the material was dried at $120{ }^{\circ} \mathrm{C}$ for $12 \mathrm{~h}$ followed by calcination at 500 ${ }^{\circ} \mathrm{C}$ for $4 \mathrm{~h}[50]$. 
The ionic liquids (1-butyl-3-methylimidazolium bis(trifluoromethylsulfonyl)imide and 1-butyl-1-methylpyrrolidinium bis(trifluoromethylsulfonyl)imide) were prepared following standard procedures from the bromide salt of the parent cation [51]. After synthesis they were dried for $24 \mathrm{~h}$ under vacuum $\left(60{ }^{\circ} \mathrm{C}, 0.02 \mathrm{mbar}\right)$ and characterized using ${ }^{13} \mathrm{C}$ and ${ }^{1} \mathrm{H}$ NMR spectroscopy and Inductively Coupled Plasma Optical Emission Spectrometry (ICP OES).

1-Butyl-3-methylimidazolium bis(trifluoromethylsulfonyl)imide [Bmim][NTf2] [52]

${ }^{1} \mathrm{H}-\mathrm{NMR}$ (500.13 MHz, DMSO-d6, $\delta$ ppm, J Hz): 9.09 (s, 1H, H-2), 7.74 (m, 1H, H-4), 7.67 (m, 1H, H-5), 4.16 (t, 2H, 7.2 Hz, H-7), 3.85 (s, 3H, H-6), 1.78 (qv, 2H, 7.2 Hz, H-8), 1.27 (sextet, 2H, 7.5 Hz, H-9), 0.91 (t, 3H, 7.5 Hz, H-10) ${ }^{13} \mathrm{C}-\mathrm{NMR}$ (125.77 MHz, DMSO-d6, $\delta$ ppm): 136.5 (C-2), 123.6 (C-5), 122.2 (C-4), 119.5 (q, 321.97 Hz, C-11 (CF $)$ ), 48.5 (C-7), 35.7 (C-6), 31.3 (C-8), 18.7 (C-9), 13.1 (C-10).

1-Butyl-1-methylpyrrolidinium bis(trifluoromethylsulfonyl)imide [Bmpyrr][NTf2] [52] ${ }^{1} \mathrm{H}-\mathrm{NMR}$ (500.13 MHz, DMSO-d 6 , $\delta$ ppm, $J$ Hz): 3.48-3.40 (m, 4H, H-2, H-5), 3.29 (m, 2H, H-7), 2.97 (s, 3H, H-6), 2.08 (m, 4H, H-3, H-4), 1.68 (m, 2H, H-8), 1.32 (sextet, 2H, 7.4 Hz, H-9), 0.93 (t, 3H, 7.4 Hz, H-10). ${ }^{13}$ C-NMR (125.77 MHz, DMSO-d6, $\delta$ ppm): 119.5 (q, 321.97 Hz, C-11 ( $\left.\left.\mathrm{CF}_{3}\right)\right), 63.4$ (t, C-2, C-5), 62.9 (t, C-7), 47.5 (t, C-6), 24.9 (C-8), 21.1 (C-4, C-3), 19.3 (C-9), 13.4 (C-10).

The SCILL-type catalysts, $5 \mathrm{wt} \% \mathrm{Pt} / \mathrm{OMS}-2 /[\mathrm{Bmim}]\left[\mathrm{NTf}_{2}\right]$ and $5 \mathrm{wt} \% \mathrm{Pt} / \mathrm{OMS}-$ 2/[Bmpyr][NTf 2$]$, were prepared by mixing a solution of $1.4 \mathrm{~mL}$ ionic liquid and $4.2 \mathrm{~mL}$ dichloromethane (1:3 (vol./vol.) ratio) with the catalyst (1g of solid) (1:2 (w/w) ratio). The SCILL suspension was then stirred for $2 \mathrm{~h}$ followed by the solvent removal under vacuum, and drying for $24 \mathrm{~h}$ under vacuum $(333.15 \mathrm{~K}, 0.02 \mathrm{mbar})$ [52]. 


\subsection{Characterization of the catalysts}

The surface area, pore volume and average pore diameter were determined from the $\mathrm{N}_{2}$ adsorption-desorption isotherms at $-196{ }^{\circ} \mathrm{C}$ using a Micromeritics ASAP 2010. Prior the nitrogen adsorption, the samples were out gassed at $120^{\circ} \mathrm{C}$, under vacuum, for $24 \mathrm{~h}$. The particle size distribution of the solids was measured at $25^{\circ} \mathrm{C}$ using Dynamic Light Scattering (DLS) in an aqueous dispersion with a Mastersizer 2000, Malvern Instruments, using the Mie scattering formalism.

H-NMR spectra were recorded on a Bruker UltraShield $500 \mathrm{MHz}$ spectrometer, operating at $11.74 \mathrm{~T}$, corresponding to the resonance frequency of $500.13 \mathrm{MHz}$ for the ${ }^{1} \mathrm{H}$ nucleus, equipped with a direct detection for nuclei probe head (BBO) and field gradients on $\mathrm{Z}$ axis. The chemical shifts are reported in ppm, using TMS as an internal standard. Typical parameters for ${ }^{1} \mathrm{H}$ NMR spectra were: $45^{\circ}$ pulse, $8.30 \mathrm{~s}$ acquisition times, $8.01 \mathrm{kHz}$ spectral window, 16 scans, $20 \mathrm{~K}$ data points delay time $1 \mathrm{~s}$. The FID was processed prior to Fourier transformation. The resonance frequency for the ${ }^{13} \mathrm{C}$ nucleus is $125.77 \mathrm{MHz}, 45^{\circ}$ pulse, 1.67 $\mathrm{s}$ acquisition times, $39.68 \mathrm{kHz}$ spectral window, $1024 \mathrm{scans}, 20 \mathrm{~K}$ data points delay time $1 \mathrm{~s}$. Powder X-ray diffraction patterns were recorded with a Shimadzu XRD 7000 diffractometer using $\mathrm{CuK}_{\alpha}$ radiation $(\lambda=1.5418 \AA, 40 \mathrm{kV}, 40 \mathrm{~mA})$ at a scanning speed of $0.10^{\circ} \cdot \mathrm{min}^{-1}$ in the $5-90^{\circ} 2 \theta$ range. Leaching of metals from the catalyst was monitored by induced coupled plasma analysis on an Agilent Technologies 715 ICP-OES apparatus. XPS analysis was carried out using Kratos AXIS Ultra DLD apparatus equipped with monochromated $\mathrm{Al} \mathrm{K} \mathrm{K}_{\alpha} \mathrm{X}$ ray source, a charge neutralizer and a hemispherical electron energy analyser with a pass energy of $160 \mathrm{eV}$. Background subtraction was performed using a Shirley background and CasaXPS software was employed to treat the data. The XPS was referenced to the aliphatic C 1s feature at $284.8 \mathrm{eV}$. Diffuse reflectance infra-red Fourier transform spectra (DRIFTS) were obtained from the accumulation of 400 scans in the domain $400-4000 \mathrm{~cm}^{-1}$ were 
recorded using a NICOLET 4700 spectrometer with diffuse reflectance accessory. DRIFT spectrawere refined by subtracting the spectrum of $\mathrm{KBr}$ used as background. Raman analysis was carried out with a Horiba Jobin Yvon - Labram HR UV-visible-NIR Raman microscope spectrometer at $633 \mathrm{~nm}$ with a beam diameter of $1.0+5 \% \mathrm{~mm}$; a spot diameter of $0.5 \mathrm{~mm}$ and spatial resolution of $0.35 \mathrm{~mm}$. SEM images were obtained using a Quanta FEG 250 Scanning Electron Microscope. The samples were prepared sonicating the material for 15 min then mounting on a specimen stub equipped with double sided tape. SEM analysis was then carried out under high vacuum and images of the sample recorded. TEM images were obtained using a Philips Tecnai F20D spectrometer with a field emission gun. The accelerating voltage was $200 \mathrm{kV}$ and the resolution was $0.2 \mathrm{~nm}$. Samples were prepared by dispersing in methanol and sonicating for $15 \mathrm{~min}$. They were analyzed on holey carbon film copper grids.

\section{3. Catalytic tests}

The oxidation of benzyl alcohol (Sigma-Aldrich, purity 99.8\%) was carried out in mixtures of $\mathrm{O}_{2}$ with $\mathrm{N}_{2}, \mathrm{He}$, Ar and $\mathrm{CO}_{2}$ as well as pure $\mathrm{O}_{2}$ (BOC, purity 99.9999\%), Scheme 1 . The tests were performed under vigorous magnetic stirring $(600 \mathrm{rpm})$ in an autoclave (reactor $316 \mathrm{SS}$, HEL Group) with a capacity of $16 \mathrm{~mL}$ using $0.02 \mathrm{~g}$ OMS-2 equivalent catalyst (for the SCILL catalyst $0.03 \mathrm{~g}$ was used to take into account the $0.01 \mathrm{~g}$ of IL), $1 \mathrm{mmol}$ benzyl alcohol and $5 \mathrm{~mL}$ deionized water. The autoclave was sealed and heated to $100{ }^{\circ} \mathrm{C}$. The reactants and products were analyzed after $4 \mathrm{~h}$ of reaction by GC-MS, after filtration and centrifugation, using a Trace GC 2000 system with MS detector (Thermo Electron Scientific Corporation, USA) incorporating a TR-WAX capillary column. The injection chamber was set up at $200^{\circ} \mathrm{C}$ and the temperature in the detector cell was $270^{\circ} \mathrm{C}$. 


\section{Scheme 1.}

\section{Results and discussion}

\subsection{Catalysts characterization}

The XRD patterns of OMS-2, Figure 1 (A1), present the typical lines corresponding to the manganese oxide octahedral molecular sieve material [53]. No another diffraction lines due to the presence of any other $\mathrm{Mn}_{\mathrm{x}} \mathrm{O}_{\mathrm{y}}$ phases were detected.

Figure 1.

The XRD of 5wt\% Pt/OMS-2 (A2) displayed no diffraction lines associated with Pt. Further deposition of ionic liquids onto the catalyst (5wt\% Pt/OMS-2/[Bmim] $\left[\mathrm{NTf}_{2}\right]$ (A3) and $5 \mathrm{wt} \% \mathrm{Pt} / \mathrm{OMS}-2 /[\mathrm{Bmpyr}]\left[\mathrm{NTf}_{2}\right]$ (A4)) did not lead to the appearance of any new diffraction lines or any shift in the existing features. The absence of any chemical change associated with the interaction of the support and ionic liquids was also confirmed by the DRIFT spectra, Figure 2.

Figure 2.

The DRIFT spectra of OMS-2 and 5wt\% Pt/OMS-2 in the region $800-400 \mathrm{~cm}^{-1}$ showed the typical absorption bands of cryptomelane $[15,53,54]$. In addition, the spectrum of $[\mathrm{Bmim}]\left[\mathrm{NTf}_{2}\right]$ show the typical absorption bands with an $\mathrm{O}-\mathrm{H}$ stretch at $3280 \mathrm{~cm}^{-1}$ and an $\mathrm{O}-\mathrm{H}$ bend at $1660 \mathrm{~cm}^{-1}$ [55]. [Bmpyr][NTf 2 showed bands at 529, 570, 619, 1054, 1139, $1197,1348,1474$ and $2966 \mathrm{~cm}^{-1}$ [56]. The bands at 570 and $1054 \mathrm{~cm}^{-1}$ are assigned to the out of plane bending of $\mathrm{N}$ and $\mathrm{S}=\mathrm{O}$ symmetric stretching weakly coupled with $\mathrm{S}-\mathrm{N}$ asymmetric 
stretching, respectively. The bands at 1139 and $1197 \mathrm{~cm}^{-1}$ correspond to the C-F stretching and C-F symmetric bending. The bands at 2881 and $2966 \mathrm{~cm}^{-1}$ correspond to symmetric and asymmetric $\mathrm{C}-\mathrm{H}$ stretching modes in the cation. No changes in the frequencies or relative intensities of the bands were found on deposition of the IL on the catalyst.

Figure 3.

The Raman spectra of OMS-2 and 5wt\% Pt/OMS-2, Figure 3 (A1, A2), show three main contributions at 183,576 and $636 \mathrm{~cm}^{-1}$ which are in accordance with literature reports for OMS-2 [57,58]. The band at $180 \mathrm{~cm}^{-1}$ corresponds to the deformation mode of the metaloxygen chain of $\mathrm{Mn}-\mathrm{O}-\mathrm{Mn}$, while the bands at 576 and $636 \mathrm{~cm}^{-1}$ correspond to the stretching modes of the Mn-O lattice. The spectra collected for the SCILL catalysts (A3, A4) showed a small shift of the band from 636 to $639 \mathrm{~cm}^{-1}$ that provides an evidence for the absence of a significant chemical change following the interaction of the IL and the catalyst. Furthermore the supported IL showed no noticeable changes in the NMR spectra [52].

XPS analysis of the SCILL catalysts showed no significant changes in the binding energies of the Pt $4 f_{7 / 2}$ level $(74.9 \mathrm{eV})$ compared with the free IL Pt/OMS-2 $(74.8 \mathrm{eV})$. They typically correspond to $\mathrm{PtO}_{2}$ [2]. The oxidation state of $\mathrm{Pt}$ has not been affected by the reaction. The same behavior is highlighted by the comparison of the $\mathrm{C} 1 \mathrm{~s}$ XPS binding energies of $5 \mathrm{wt} \% \mathrm{Pt} / \mathrm{OMS}-2 /[\mathrm{Bmim}]\left[\mathrm{NTf}_{2}\right] /$ pure ionic liquid $\left[\mathrm{Bmim}^{2}\left[\mathrm{NTf}_{2}\right]\right.$ namely $\mathrm{C}$ aliphatic chain: $284.8 / 284.7 \mathrm{eV}$; $\mathrm{N}$ bonded $\mathrm{C}$ aliphatic chain: 285.6/285.9 eV; C-C*-N imidazolium ring: 286.9/286.5 eV; $\mathrm{N}-\mathrm{C}^{*}-\mathrm{N}$ imidazolium ring: 286.9/287.1 eV and $-\mathrm{SO}_{2}-\mathrm{CF}_{3}$ : 293.0/292.6 eV [2,52,59]. Moreover, in the case of Mn there are no changes in the binding energies following deposition of the ionic liquid layer. At $641.7 \mathrm{eV}$ is positioned the $\mathrm{Mn} 2 \mathrm{p}_{3 / 2}$ photoelectron peak assigned to the $\mathrm{Mn}^{4+}$. The peak at a binding energy of $529.2 \mathrm{eV}$ is 
assigned of lattice oxygen $\left(\mathrm{O}^{2-}\right)$ and the peak at $532.2 \mathrm{eV}$ is characteristic to the surface oxygen ions with lower valence as well as in the hydroxyl form $[2,50]$.

The BET surface area was $59.0 \mathrm{~m}^{2} \cdot \mathrm{g}^{-1}$ and $0.16 \mathrm{~cm}^{3} \cdot \mathrm{g}^{-1}$ pore volume for OMS-2. The presence of platinum led to a decrease in the surface area to $48.5 \mathrm{~m}^{2} \cdot \mathrm{g}^{-1}$ and pore volume to $0.11 \mathrm{~cm}^{3} \cdot \mathrm{g}^{-1}[50]$. Both SCILL catalysts display the ionic liquid loading $\varepsilon$, pore filling degree $\alpha$ and the layer thickness SIL [60] approximately identical $\left(5 \mathrm{wt} \% \mathrm{Pt} / \mathrm{OMS}-2 /[\mathrm{Bmim}]\left[\mathrm{NTf}_{2}\right] \varepsilon\right.$ $=50 \%, \alpha=19 \%$, SIL $=28 \mathrm{~nm} ; 5 \mathrm{wt} \% \mathrm{Pt} / \mathrm{OMS}-2 /[\mathrm{Bmpyr}]\left[\mathrm{NTf}_{2}\right] \varepsilon=50 \%, \alpha=19.5 \%, \mathrm{SIL}=29$ $\mathrm{nm})$. Therefore, pores are not fully filled with the ionic liquid; however, the IL is present as a multilayer. It should be noted that it is likely that for a filling degree of $19 \%$, the small pores are likely to be completely filled [60].

SEM and TEM images for OMS-2 and 5\%wt Pt/OMS-2 are shown in Figure 4. SEM images for both materials OMS-2 (a) and 5\%Pt/OMS-2 (b), both materials showed the characteristic nano-rod like morphology of OMS-2. There is no notable difference between the OMS-2 and the 5\%wt Pt/OMS-2 samples. The nano-rods range approximately in size from 160-240 $\mathrm{nm}$ in length and $20 \mathrm{~nm}$ in width. The TEM image of 5\%Pt/OMS-2 (d) showed uniform distribution of spherical Pt nanoparticles of mean diameter $\sim 1.2 \mathrm{~nm}$ present on the surface of OMS-2 molecular sieves.

Figure 4.

The DLS measurements, Figure 5 showed an aggregation of the particles under working solvent conditions. The aggregation of the catalysts particles in water was different as a function of the type of the IL producing the SCILLs. $5 \mathrm{wt} \% \mathrm{Pt} / \mathrm{OMS}-2$ aggregated in larger particles than the two SCILL catalysts showing a protecting effect of the IL shell 
(80.27 $\mu \mathrm{m}$ versus $43.15 \mu \mathrm{m}$ and $49.48 \mu \mathrm{m}$, respectively). Between the two ILs, [Bmim][NTf 2 ] afforded smaller particles than [Bmpyr][NTf 2$]$.

Figure 5.

\subsection{Catalytic tests}

Makwana et all [61] suggested that on OMS-2 this oxidation reaction occurs following an Mars-van Krevelen mechanism involving two steps: i) oxidation of the substrate by the oxygen emerged from the solid lattice, and ii) re-oxidation of the solid with molecular oxygen. Accordingly, in the first step $\mathrm{Mn}^{4+}$ is reduced to $\mathrm{Mn}^{2+}$ and re-oxidized to $\mathrm{Mn}^{4+}$ the second step. The analysis of the reaction products indicated only benzaldehyde and benzoic acid, irrespective of the reaction conditions. Using 5 atm $\mathrm{O}_{2}$ at $100{ }^{\circ} \mathrm{C}$, the $\mathrm{OMS}-2$ support exhibited a small activity (ca. 20\% conversion after $4 \mathrm{~h}$ ) but after the addition of $5 \mathrm{wt} \%$ platinum $100 \%$ conversion was observed, Figure $6 \mathrm{~A}$. The selectivity to aldehyde and acid was not influenced by the presence of Pt with $94 \%$ aldehyde and $6 \%$ acid found for both OMS-2 and 5wt\% Pt/OMS-2. For the SCILL catalysts the activity is influenced by the presence of the IL with the addition of $[\mathrm{Bmim}]\left[\mathrm{NTf}_{2}\right]$ to the $5 \mathrm{wt} \% \mathrm{Pt} / \mathrm{OMS}-2$ leading to a decrease in conversion (47\%) with no change in the selectivity. A smaller decrease was

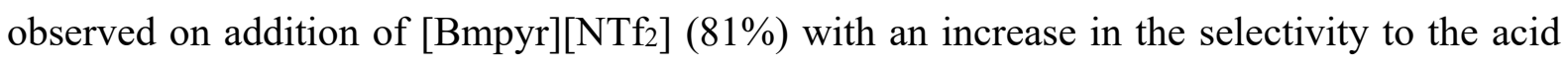
from $6 \%$ to $25 \%$ with the balance aldehyde. Replacing 5 atm oxygen with 25 atm of $20 \% \mathrm{O}_{2}$ in $\mathrm{N}_{2}$ (i.e. the equivalent partial pressure of $\mathrm{O}_{2}$ ), Figure $6 \mathrm{~B}$, did not affect the activity of OMS-2 or $5 \mathrm{wt} \%$ Pt/OMS-2 but did decrease the selectivity towards aldehyde from $94 \%$ to $83 \%$ for OMS-2 and to $39 \%$ for $5 \mathrm{wt} \% \mathrm{Pt} / \mathrm{OMS}-2$, respectively. Interestingly, whilst the conversion and selectivity over the $5 \mathrm{wt} \% \mathrm{Pt} / \mathrm{OMS}-2 /[\mathrm{Bmpyr}]\left[\mathrm{NTf}_{2}\right]$ remained similar for each gas atmosphere, a significant increase in conversion was observed for $5 \mathrm{wt} \% \mathrm{Pt} / \mathrm{OMS}$ - 
$2 /[\mathrm{Bmim}]\left[\mathrm{NTf}_{2}\right]$ from $47 \%$ to $80 \%$ with a decrease in selectivity to the aldehyde from $94 \%$ to $82 \%$.

Figure 6.

To estimate the influence of the diffusion upon the reaction rate in the investigated oxidation, at 5 atm $\mathrm{O}_{2}$, the Weisz-Prater criterion [62] has been calculated for all the investigated solid catalysts, using Eq. 1.

$$
N_{W-P}=\frac{R \cdot \rho_{p} \cdot R_{p}^{2}}{C_{s} \cdot D_{e f}}
$$

where: $\mathrm{R}$ is the reaction rate, $\rho_{\mathrm{p}}$ is the catalyst particle density $\left(\mathrm{g} / \mathrm{cm}^{3}\right), \mathrm{R}_{\mathrm{p}}$ is the catalyst particle radius, $C_{s}$ is the reactant concentration at the particle surface and $D_{\text {ef }}$ is the effective diffusivity, calculated according to Levenspiel [63].

The values of this criterion smaller than 0.3 confirm the absence of any pore diffusion limitations (OMS-2 - 0.03 $10^{-6} ; 5 \%$ Pt/OMS-2 - 0.16 $10^{-6} ; 5 \%$ Pt/OMS-2/[Bmim][NTf 2$]-$ $\left.0.07 \cdot 10^{-6} ; 5 \% \mathrm{Pt} / \mathrm{OMS}-2 /[\mathrm{Bmpyr}]\left[\mathrm{NTf}_{2}\right]-0.13 \cdot 10^{-6}\right)$. Besides this, the solubility of the reactants through the ionic liquid layer (Henry's constant) exerts an important influence upon the catalytic properties of SCILL materials (further exemplified in Figure 9).

Figure 7 presents the time evolution of the conversion for the oxidation of benzyl alcohol in the presence of SCILL catalysts, at 5 atm $\mathrm{O}_{2}$. It corresponds to a linear increase of the conversion, with a more pronounced decrease in the selectivity to benzaldehyde for $5 \mathrm{wt} \%$ $\mathrm{Pt} / \mathrm{OMS}-2 /[\mathrm{Bmpyr}]\left[\mathrm{NTf}_{2}\right]$ than for the $5 \mathrm{wt} \% \mathrm{Pt} / \mathrm{OMS}-2 /[\mathrm{Bmim}]\left[\mathrm{NTf}_{2}\right]$ catalyst. However, while the conversion reached a plateau after $9 \mathrm{~h}$, the selectivity continued to deplete in the favor of benzoic acid. This is more evident for $\left.5 \mathrm{wt} \% \mathrm{Pt} / \mathrm{OMS}-2 /[\mathrm{Bmpyr}] \mathrm{NTf}_{2}\right]$. 
Figure 7.

For the SCILL catalysts, the increase of the $\mathrm{O}_{2}$ pressure from 5 atm to $25 \mathrm{~atm}$, Figure 8, corresponds to a gradual increase in conversion reaching $81 \%$ for $5 \mathrm{wt} \% \mathrm{Pt} / \mathrm{OMS}$ 2/[Bmim] $\left[\mathrm{NTf}_{2}\right]$, and $96 \%$ for $5 \mathrm{wt} \% \mathrm{Pt} / \mathrm{OMS}-2 /[\mathrm{Bmpyr}]\left[\mathrm{NTf}_{2}\right]$ at the highest pressure. Under the same conditions, the selectivity towards aldehyde decreased from $93 \%$ to $80 \%$ for $5 \mathrm{wt} \%$ $\mathrm{Pt} / \mathrm{OMS}-2 /[\mathrm{Bmim}]\left[\mathrm{NTf}_{2}\right]$ and from $76 \%$ to $68 \%$ for $5 \mathrm{wt} \% \mathrm{Pt} / \mathrm{OMS}-2 /[\mathrm{Bmpyr}]\left[\mathrm{NTf}_{2}\right]$. As expected for a consecutive reaction, the lower conversions lead to the higher selectivity of the aldehyde.

Figure 8.

In order to evaluate any changes in the catalysts following reaction, XRD, Figure 1 (B1 - B4), and Raman spectra, Figure 3 (B1 - B4), were collected for used solids after the oxidation of benzyl alcohol under 25 atm $\mathrm{O}_{2}$. They confirmed that OMS-2 has been not altered (B1). However, for the 5wt\% Pt/OMS-2 catalyst (B2), a significant decrease in the intensity of diffraction lines of the cryptomelane structure accompanied by the presence of new lines assigned to $\mathrm{Mn}_{3} \mathrm{O}_{4}$ [48], which have been indexed to those of hausmannite (a complex oxide of manganese containing both di- and tri-valent manganese, $\mathrm{Mn}^{2+} \mathrm{Mn}^{3+}{ }_{2} \mathrm{O}_{4}$ ), was observed. In contrast, although both the SCILL catalysts, (5wt $\%$ Pt/OMS2/[Bmim] $\left[\mathrm{NTf}_{2}\right](\mathrm{B} 3)$ and $\left.5 \mathrm{wt} \% \mathrm{Pt} / \mathrm{OMS}-2 /[\mathrm{Bmpyr}]\left[\mathrm{NTf}_{2}\right](\mathrm{B} 4)\right)$, also show XRD features corresponding to $\mathrm{Mn}_{3} \mathrm{O}_{4}$ their intensity was significantly lower than that of the $5 \mathrm{wt} \%$ Pt/OMS-2 sample in the absence of the IL indicating that the IL enhances the structural stability of the catalyst. In all cases, the ICP-OES analysis detected no leaching of metals 
from the catalysts (K, Pt, Mn). In addition, whilst there was a change in the OMS-2 structure, features associated with Pt species were observed following reaction.

Raman spectra of the catalyst post reaction, Figure 3 (B1-B4), showed a shift in the position of the band from 576 to $568 \mathrm{~cm}^{-1}$ and of that at 639 to $643 \mathrm{~cm}^{-1}$ which is also consistent with the stretching modes of $\mathrm{Mn}-\mathrm{O}$ lattice undergoing modification during reaction.

The higher activity for the $5 \mathrm{wt} \% \mathrm{Pt} / \mathrm{OMS}-2 /[\mathrm{Bmpyr}]\left[\mathrm{NTf}_{2}\right]$ in the presence of $25 \mathrm{~atm}$ $20 \% \mathrm{O}_{2}$ in $\mathrm{N}_{2}$ compared with the 5 atm of $100 \% \mathrm{O}_{2}$ indicates that the presence of diluent gas can affect the conversion and selectivity observed. This behavior has been observed previously [64]. In order to establish the influence of the inert gas on the catalytic activity of the SCILL catalysts, reactions in the presence of different inert $\left(\mathrm{He}, \mathrm{Ar}, \mathrm{N}_{2}\right)$ or reactive $\mathrm{CO}_{2}$ gas mixtures were performed.

Figure 9A shows that for $5 \mathrm{wt} \% \mathrm{Pt} / \mathrm{OMS}-2 /[\mathrm{Bmim}]\left[\mathrm{NTf}_{2}\right]$, the catalyst showed an increase of the activity when the gas composition changed from inert or reactive gas $/ \mathrm{O}_{2}$ for all gas pressures in the same order: $\mathrm{He}>\mathrm{Ar}>\mathrm{N}_{2}>\mathrm{CO}_{2}$ with the largest change observed between $\mathrm{CO}_{2}$ and $\mathrm{N}_{2}$ and a small change observed between $\mathrm{Ar}$ and He. The changes associated with the change in the inert gas may be associated with competition of the gas solubility between $\mathrm{O}_{2}$ and the inert within the IL leading to changes in $\mathrm{O}_{2}$ solubility. For example, the solubility of $\mathrm{N}_{2}$ in the pure IL is higher than that of $\operatorname{Ar}\left(1 \mathrm{~atm}\right.$ and $70{ }^{\circ} \mathrm{C}$, the Henry's constant of $\mathrm{N}_{2}$ is $\mathrm{K}_{\mathrm{H}} / 10^{5} \mathrm{~Pa}=3064$ versus $\mathrm{K}_{\mathrm{H}} / 10^{5} \mathrm{~Pa}=2707$ of $\mathrm{Ar}$ ), [65] which may result in a decrease in $\mathrm{O}_{2}$ solubility for the $\mathrm{N}_{2}$ gas mixture compared with Ar. In the case of $\mathrm{CO}_{2}$, its very high solubility in ILs [66] may account for a large decrease in the solubility of oxygen and, therefore, smaller conversions. The effect of the $\mathrm{CO}_{2}$ may also be to interact with the OMS-2 leading to reduced surface oxygen mobility and a decrease in the ability to undergo the Mar-van-Krevelen mechanism. In addition, with increasing $\mathrm{O}_{2}$ partial pressure 
the conversion increased in line with the results shown in Figure 8. The selectivity to aldehyde decreased with the increase of conversion, as expected. It should be noted that whilst similar trends, especially comparing $\mathrm{CO}_{2}$ and the inert gases as the diluent gas, were also observed for the 5\% Pt/OMS-2/[Bmpyr][ $\left.\mathrm{NTf}_{2}\right]$, Figure $9 \mathrm{~B}$, i.e. on changing the cation, the influence of the change in the inert gas is smaller. This may be associated with the water content of the IL in each case which will change the solubility of the gases significantly and varies from saturation values of 0.252 (expressed in water mole fraction at $23{ }^{\circ} \mathrm{C}$ ) [67] and $0.2568[68]$ in the $[\mathrm{Bmpyr}]\left[\mathrm{NTf}_{2}\right]$ and $[\mathrm{Bmim}]\left[\mathrm{NTf}_{2}\right]$, respectively.

The size of the catalytic aggregates plays also a role in this oxidation. Larger particles led to higher conversions of the substrate $(5 \mathrm{wt} \% \mathrm{Pt} / \mathrm{OMS}-2>5 \mathrm{wt} \% \mathrm{Pt} / \mathrm{OMS}-$ $\left.2 /\left[\mathrm{Bmpyr}_{[}\right]\left[\mathrm{NTf}_{2}\right]>5 \mathrm{wt} \% \mathrm{Pt} / \mathrm{OMS}-2 /\left[\mathrm{Bmim}^{2}\right]\left[\mathrm{NTf}_{2}\right]\right)$, Figure $6 \mathrm{~A}$. The selectivity of the catalysts has been only influenced by the nature of IL. The composition of the oxidative atmosphere has an influence only for the case of nitrogen. For the same conversion, i.e. $82 \%$, replacing air (where the selectivity to aldehyde changed from $84.6 \%$ (5wt $\%$ Pt/OMS2/[Bmim] $\left.\left[\mathrm{NTf}_{2}\right]\right)$ to $\left.77.4 \%\left(5 \mathrm{wt} \% \mathrm{Pt} / \mathrm{OMS}-2 /\left[\mathrm{Bmpyr}_{[}\right] \mathrm{NTf}_{2}\right]\right)$ led to close selectivities. With $\mathrm{He} / \mathrm{O}_{2}$ or $\mathrm{Ar} / \mathrm{O}_{2}$ mixture (the same molar ratio) this was pretty similar (in $\mathrm{He} 83.3 \% / 82.9 \%$ and $\operatorname{Ar} 75.2 \% / 75.6 \%)$.

Figure 9.

Pt/OMS-2/[Bmim] $\left[\mathrm{NTf}_{2}\right]$ can be easily separated by a simple filtration and can be reused several times. Thus, working at 5 atm $\mathrm{O}_{2}$, we found no visible changes for the first three successive cycles. After that, the conversion starts to decrease till $90 \%$ from the initial value. However, the selectivity remained almost unchanged. 


\section{Conclusions}

The cryptomelane form of manganese oxide catalyst, OMS-2, exhibits a low catalytic activity in the oxidation of benzyl alcohol in the presence of air or molecular oxygen as oxidants. The presence of only $5 \mathrm{wt} \%$ platinum led to a total conversion of benzyl alcohol. The thin ILs layer, $\left([\mathrm{Bmim}]\left[\mathrm{NTf}_{2}\right]\right.$ or $\left.[\mathrm{Bmpyr}]\left[\mathrm{NTf}_{2}\right]\right)$, covering both the support and $5 \mathrm{wt} \% \mathrm{Pt} / \mathrm{OMS}-2$, modifies the selectivity to benzaldehyde. Under the catalytic conditions the catalysts nanoparticles aggregate, and the aggregation depended on the nature of IL. ([Bmim] $\left.\mathrm{NTf}_{2}\right]$ preserved particles with smaller dimensions. However, the application of the Weisz-Prater criterion confirmed the absence of diffusional constraints in all the cases. Using SCILL catalysts, the increase of the oxygen pressure led to an increase in the conversion in the detriment of selectivity. The presence of platinum on the surface results in changes of OMS-2 with the formation of $\mathrm{Mn}_{3} \mathrm{O}_{4}$. The presence of the ionic liquid on the surface of SCILL reduces the degradation of the support structure. Different mixture such as $\mathrm{N}_{2}, \mathrm{He}, \mathrm{Ar}, \mathrm{CO}_{2} /$ $\mathrm{O}_{2}$ led to significant changes in selectivity and conversion indicating that the oxygen solubility in the IL may be controlled by the diluent gas and has an important effect on the oxidation of benzyl alcohol.

\section{Acknowledgments}

The UK Catalysis Hub is kindly thanked for resources and support provided via our membership of the UK Catalysis Hub Consortium and funded by EPSRC (grants EP/K014706/1, EP/K014668/1, EP/K014854/1, EP/K014714/1 and EP/M013219/1). 


\section{References}

[1] R.N. DeGuzman, Y.-F. Shen, E.J. Neth, S.L. Suib, C.-L. O'Young, S. Levine, J.M. Newsam, Chem. Mater. 6 (1994) 815-821.

[2] I.J. McManus, H. Daly, H.G. Manyar, S.F.R. Taylor, J.M. Thompson, C. Hardacre, Faraday Discuss. 188 (2016) 451-466.

[3] A.R. Gandhea, J.S. Rebello, J.L. Figueiredo, J.B. Fernandes, Appl. Catal. B-Environ. 72 (2007) 129-135.

[4] V.V. Dutov, G.V. Mamontov, V.I. Sobolev, O.V. Vodyankina, Catal. Today 278 (2016) $164-173$

[5] J. Li, R. Wang, J. Hao, J. Phys. Chem. C 114 (2010) 10544-10550

[6] C. Calvert, R. Joesten, K. Ngala, J. Villegas, A. Morey, X. Shen, S.L. Suib, Chem. Mater. 20 (2008) 6382-6388.

[7] G. D. Yadav, H. G. Manyar, Adv. Synth. Catal. 350 (2008) 2286- 2294.

[8] G. D. Yadav, S. Subramanian, H. G. Manyar, Org. Proc. Res. \& Dev. 14 (2010) 537-543.

[9] B. Hu, C.-hu Chen, S.J. Frueh, L. Jin, R. Joesten. S.L. Suib, J. Phys. Chem. C 114 (2010) $1149835-9844$.

[10] S.L. Suib, J. Mater. Chem. 18 (2008) 1623-1631.

[11] M. Abecassis-Wolfovich, R. Jothiramalingam, M.V. Landau, M. Herskowitz, B. Viswanathan, T.K. Varadarajan, Appl. Catal. B-Environ. 59 (2005) 91-98.

[12] J. Huang, A.S. Poyraz, S.-Y. Lee, L. Wu, Y. Zhu, A.C. Marschilok, K.J. Takeuchi, E.S. Takeuchi, ACS Appl. Mater. Interfaces, Article ASAP, DOI: 10.1021/acsami.6b08549.

[13] J.R. Kona, C.K. King'ondu, A.R. Howell, S.L. Suib, ChemCatChem 6 (2014) 749- 752.

[14] Y.F. Shen, R.P. Zerger, R.N. DeGuzman, S.L. Suib, L. McCurdy, D. I. Potter, C.L. O'Young, Science 260 (1993) 511-515. 
[15] S. Dharmarathna, C.K. King'ondu, L. Pahalagedara, C.-H. Kuo,Y. Zhang, S.L. Suib, Appl. Catal. B-Environ. 147 (2014) 124-131.

[16] W.-N. Li, J. Yuan, X.-F. Shen, S. Gomez-Mower, L.-P. Xu, S. Sithambaram, M. Aindow, S.L. Suib, Adv. Funct. Mater. 16 (2006) 1247-1253.

[17] R. Kumar, S. Sithambaram, S.L. Suib, J.Catal. 262 (2009) 304-313

[18] L. Wang, C. Zhang, H. He, F. Liu, C. Wang, J. Phys. Chem. C 120 (2016) 6136-6144

[19] R. Jothiramalingam, B. Viswanathan, T.K. Varadarajan, J. Mol. Catal. A: Chem. 252 (2006) 49-55.

[20] M. Sun, F. Ye, B. Lan, L. Yu, X. Cheng, S. Liu, X. Zhang, Int. J. Electrochem. Sci. 7 (2012) 9278- 9289.

[21] D. Zhao, M. Wu, Y. Kou, E. Min, Catal. Today 74 (2002) 157-189.

[22] H. Zhao, S. Xia, P. Ma, J. Chem. Technol. Biotechnol. 80 (2005) 1089-1096.

[23] D. Betz, P. Altmann, M. Cokoja, W.A. Herrmann, F.E. Kühn, Coord. Chem. Rev. 255 (2011) 1518-1540.

[24] V.I. Parvulescu, C. Hardacre, Chem. Rev. 107 (2007) 2615-2665.

[25] M.J. Earle, J.M.S.S. Esperança, M.A. Gilea, J.N. Canongia Lopes, L.P.N. Rebelo, J.W. Magee, K.R. Seddon, J.A. Widegren, Nature 439 (2006) 831-834.

[26] J. Dupont, R.F. de Souza, P.A.Z. Suarez, Chem. Rev. 102 (2002) 3667- 3692.

[27] C.P. Mehnert, E.J. Mozeleski, R.A. Cook, Chem. Commun. (2002) 3010-3011.

[28] C. P. Mehnert, R. A. Cook, N. C. Dispenziere, M. Afeworki, J. Am. Chem. Soc. 124 (2002) 12932-12933.

[29] A. Riisager, K.M. Eriksen, P. Wasserscheid, R. Fehrmann, Catal. Lett. 90 (2003) 149153.

[30] A. Riisager, P. Wasserscheid, R. van Hal, R. Fehrmann, J. Catal. 219 (2003) 452-455.

[31] T. Selvam, A. MacHoke, W. Schwieger, Appl. Catal. A-Gen. 445-446 (2012) 92-101. 
[32] A. Jess, W. Korth, B. Etzold, Ger. Offen. DE 102006019460 (2007).

[33] U. Kernchen, B. Etzold, W. Korth, A. Jess, Chem. Eng. Technol. 30 (2007) 985-994.

[34] R. Meijboom, M. Haumann, T. E. Müller and N. Szesni, Synthetic methodologies for supported ionic liquid materials, in Supported Ionic Liquids - Fundamentals and Applications, ed. R. Fehrmann, A. Rissager and M. Haumann, Wiley-VCH, Weinheim, 2013. [35] J. Arras, M. Steffan, Y. Shayeghi, P. Claus, Chem. Commun. (2008) 4058-4060.

[36] E. Bogel-Łukasik, S. Santos, R. Bogel-Łukasik, M.N. da Ponte, J. Supercrit. Fluids 54 (2010) 210-217.

[37] M.F. Friedrich, M. Lucas, P. Claus, Catal. Commun. 88 (2017) 73-76.

[38] S.F. Miller, H.B. Friedrich, C.W. Holzapfel, ChemCatChem 4 (2012) 1337-1344.

[39] C. Meyer, V. Hager, W. Schwieger, P. Wasserscheid, J. Catal. 292 (2012) 157-165.

[40] R. Yamamoto, Y. Sawayama, H. Shibahara, Y. Ichihashi, S. Nishiyama, S. Tsuruya, J. Catal. 234 (2005) 308-317.

[41] C.D. Pina, E. Falletta, M. Rossi, J. Catal. 260 (2008) 384-386.

[42] Ullmann's Encyclopedia of Industrial Chemistry, $7^{\text {th }}$ Edition, 2011.

[43] R. Marotta, I. Di Somma, D. Spasiano, R. Andreozzi, V. Caprio, Chem. Eng. J. 172 (2011) 243-249.

[44] A. Jia, L.-L. Lou, C. Zhang, Y. Zhang, S. Liu, J. Mol. Catal. A: Chem. 306 (2009) 123129.

[45] J. Luo, H. Yu, H. Wang, H. Wang, F. Peng, Chem. Eng. J. 240 (2014) 434-442.

[46] M. Sadiq, M. Ilyas, S. Alam, Tenside, Surfactants, Deterg. 49 (2012) 37-42.

[47] I. Mohammad, S. Mohsin, S. Muhammad, Chin. Sci. Bull. 58 (2013) 2354-2359.

[48] N.N. Opembe, C. Guild, C. King’ondu, N.C. Nelson, I.I. Slowing, S.L. Suib, Ind. Eng. Chem. Res. 53 (2014) 19044-19051.

[49] N. Duan, S. L. Suib, C.-L. O’Young, Chem. Commun. 1992, 1213-1214. 
[50] H.G. Manyar, B. Yang, H. Daly, H. Moor, S. McMonagle, Y. Tao, G.D. Yadav, A. Goguet, P. Hu, C. Hardacre, ChemCatChem 5 (2013) 506-512.

[51] D. Zhao, Z. Fei, R. Scopelliti and P. Dyson, J. Inorg. Chem. 43 (2004) 2197-205.

[52] O.D. Pavel, I. Podolean, V.I Pârvulescu, S.F.R. Taylor, H. Manyar, K. Ralphs, P. Goodrich, C. Hardacre, Faraday Discuss. 2017, doi:10.1039/C7FD00159B.

[53] C.C. King'ondu, N. Opembe, C. Chen, K. Ngala, H. Huang, A. Iyer, H.F. Garcés, S.L. Suib, Adv. Funct. Mater. 21 (2011) 312-323.

[54] L.J. Garces, B. Hincapie, V.D. Makwana, K. Laubernds, A. Sacco, S.L. Suib, Micropor. Mesopor. Mat. 63 (2003) 11-20.

[55] H.-J. Liaw, C.-C. Chen, Y.-C. Chen, J.-R. Chen, S.-K. Huanga, S.-N. Liuc, Green Chem. 14 (2012) 2001-2008.

[56] M. Shukla, S. Saha, "A Comparative Study of Piperidinium and Imidazolium Based Ionic Liquids: Thermal, Spectroscopic and Theoretical Studies", in "Ionic Liquids - New Aspects for the Future", Edited by Jun-ichi Kadokawa, Publisher: InTech, January 23, 2013.

[57] L.R. Pahalagedara, S. Dharmarathna, C.K. King'ondu, M. N. Pahalagedara, Y-T. Meng, C.-H. Kuo, S. L. Suib, J. Phys. Chem. C, 118 (2014) 20363-20373.

[58] R. Wang, J. Li, Catal. Lett. 131 (2009) 500-505.

[59] O. Hofft, S. Bahr, M. Himmerlich, S. Krischok, J.A. Schaefer and V. Kempter, Langmuir 22 (2006) 7120-7123.

[60] F. Heym, C. Kern, J. Thiessen, A. Jess, "Pore Volume and Surface Area of Supported Ionic Liquids Systems", Chapter V, in "Supported Ionic Liquids: Fundamentals and Applications", Edited by R. Fehrmann, A. Riisager and M. Haumann, 2014 Wiley-VCH Verlag GmbH \& Co.

[61] V.D. Makwana, Y.-C. Son, A.R. Howell, S.L. Suib, J. Catal. 210 (2002) 46-52.

[62] P.B. Weisz, C.D. Prater, Adv. Catal. 6 (1954) 143-196. 
[63] O. Levenspiel, Chemical Reaction Engineering, $3^{\text {rd }}$ Edn, John Wiley \& Sons, Ch 3, 1999. [64] O.D. Pavel, P. Goodrich, L. Cristian, S.M. Coman, V.I. Pârvulescu, C. Hardacre, Catal. Sci. Technol. 5 (2015) 2696-2704.

[65] J. Jacquemin, M.F. Costa Gomes, P. Husson, V. Majer, J. Chem. Thermodynamics 38 (2006) 490-502.

[66] Z. Lei, C. Dai and B. Chen, Chem. Rev. 114 (2014) 1289-1326.

[67] M.G. Freire, C.M.S.S. Neves, K. Shimizu, C.E.S. Bernardes, I.M. Marrucho, J.A.P. Coutinho, J.N. Canongia Lopes, L.P.N. Rebelo, J. Phys. Chem. B 114 (2010) 15925-15934. [68] M.G. Freire, P.J. Carvalho, R.L. Gardas, I.M. Marrucho, L.M.N.B.F. Santos, J.A.P. Coutinho, J. Phys. Chem. B 112 (2008) 1604-1610. 


\section{Caption of Schemas:}

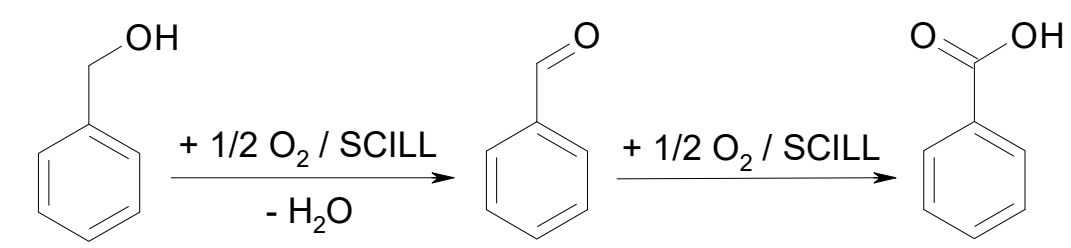

Benzyl alcohol

Benzaldehyde

Benzoic acid

Scheme 1. The selective oxidation of benzyl alcohol with molecular oxygen. 


\section{Figure Captions:}

Figure 1. The XRD patterns of fresh solids (A1 - OMS-2; A2 - 5\%wt Pt/OMS-2; A3 - 5\% $\mathrm{Pt} / \mathrm{OMS}-2 /[\mathrm{Bmim}]\left[\mathrm{NTf}_{2}\right]$ and A4 - 5\% Pt/OMS-2/[Bmpyr] $\left.\left[\mathrm{NTf}_{2}\right]\right)$ and used after oxidation of benzyl alcohol at 25 atm $\mathrm{O}_{2}$ (B1 - OMS-2; B2 - 5\%wt Pt/OMS-2; B3 - 5\% Pt/OMS2/[Bmim] $\left[\mathrm{NTf}_{2}\right]$ and B4 - 5\% Pt/OMS-2/[Bmpyr][NTf 2$\left.]\right)$

Figure 2. The DRIFT spectra of solids, ionic liquids and SCILL catalysts

Figure 3. Raman spectra of fresh solids (A1 - OMS-2; A2 - 5\%wt Pt/OMS-2; A3 - 5\% $\mathrm{Pt} / \mathrm{OMS}-2 /[\mathrm{Bmim}]\left[\mathrm{NTf}_{2}\right]$ and A4 - 5\% $\left.\mathrm{Pt} / \mathrm{OMS}-2 /[\mathrm{Bmpyr}]\left[\mathrm{NTf}_{2}\right]\right)$ and used after the oxidation of benzyl alcohol at 25 atm $\mathrm{O}_{2}$ (B1 - OMS-2; B2 - 5\%wt Pt/OMS-2; B3 - 5\% $\mathrm{Pt} / \mathrm{OMS}-2 /[\mathrm{Bmim}]\left[\mathrm{NTf}_{2}\right]$ and B4 - 5\% Pt/OMS-2/[Bmpyr][NTf 2$\left.]\right)$

Figure 4. SEM image of OMS-2 (a), SEM image 5\%wt Pt/OMS-2 (b), TEM image of OMS2 (c), TEM image of 5\%wt Pt/OMS-2 (d)

Figure 5. Particle size distributions measured by dynamic light scattering

Figure 6. The conversion of benzyl alcohol and selectivity to benzaldehyde and benzoic acid over the investigated catalysts in the presence of 5 atm $\mathrm{O}_{2}$ (A) and 25 atm air (B), respectively, $100^{\circ} \mathrm{C}, 4 \mathrm{~h}$.

Figure 7. Time evolution of the conversion for the oxidation of benzyl alcohol in the presence of the SCILL catalysts at 5 atm $\mathrm{O}_{2}, 100^{\circ} \mathrm{C}, 4 \mathrm{~h}$

Figure 8. SCILLs activity vs. the molecular oxygen pressure, $100^{\circ} \mathrm{C}, 4 \mathrm{~h}$

Figure 9. The variation of the conversion of benzyl alcohol as a function of the gas mixture composition (A - 5\% Pt/OMS-2/[Bmim][NTf 2$]$; B - 5\% Pt/OMS-2/[Bmpyr] $\left.\left[\mathrm{NTf}_{2}\right]\right), 100{ }^{\circ} \mathrm{C}$, $4 \mathrm{~h}$ 


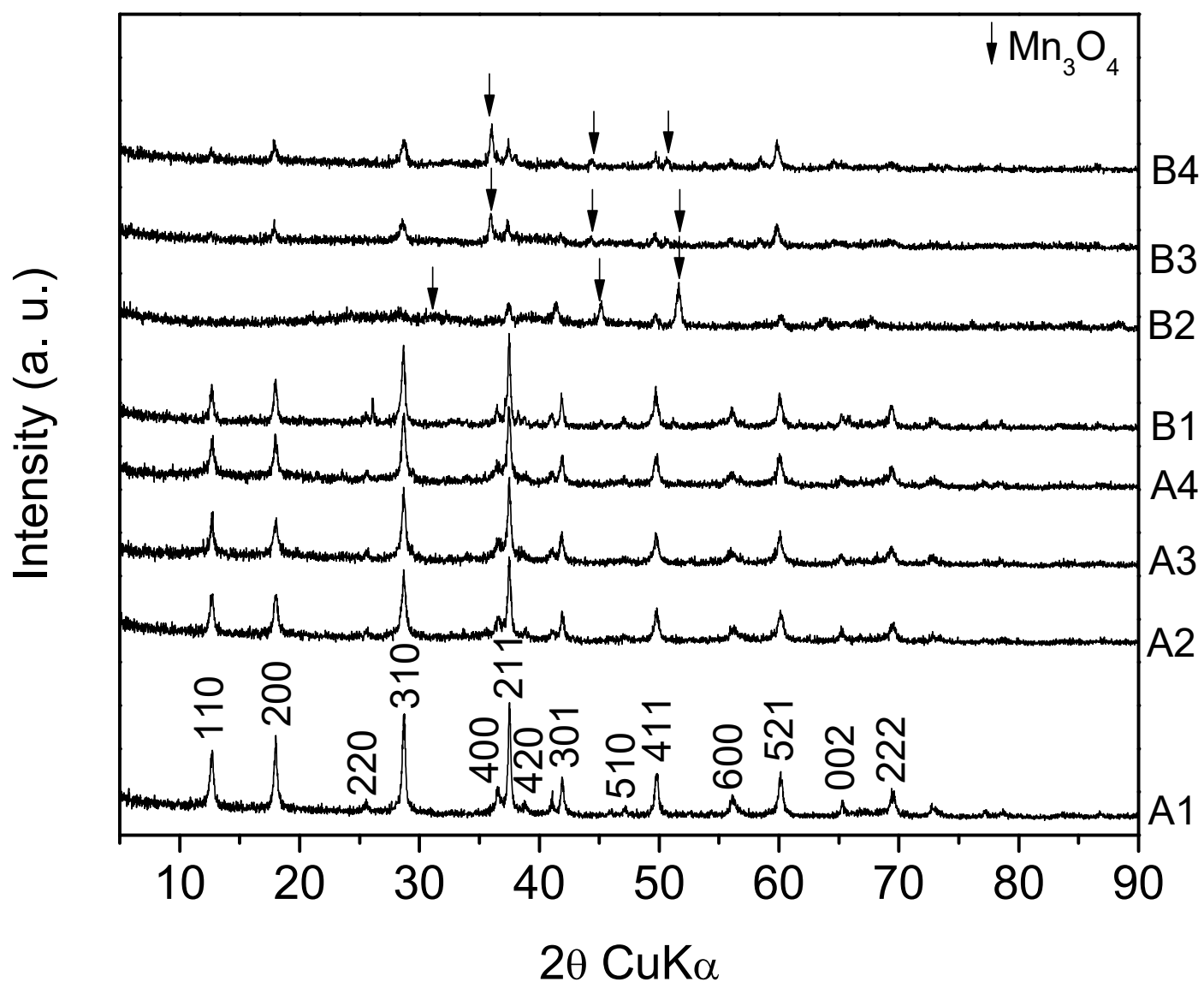

Figure 1. 


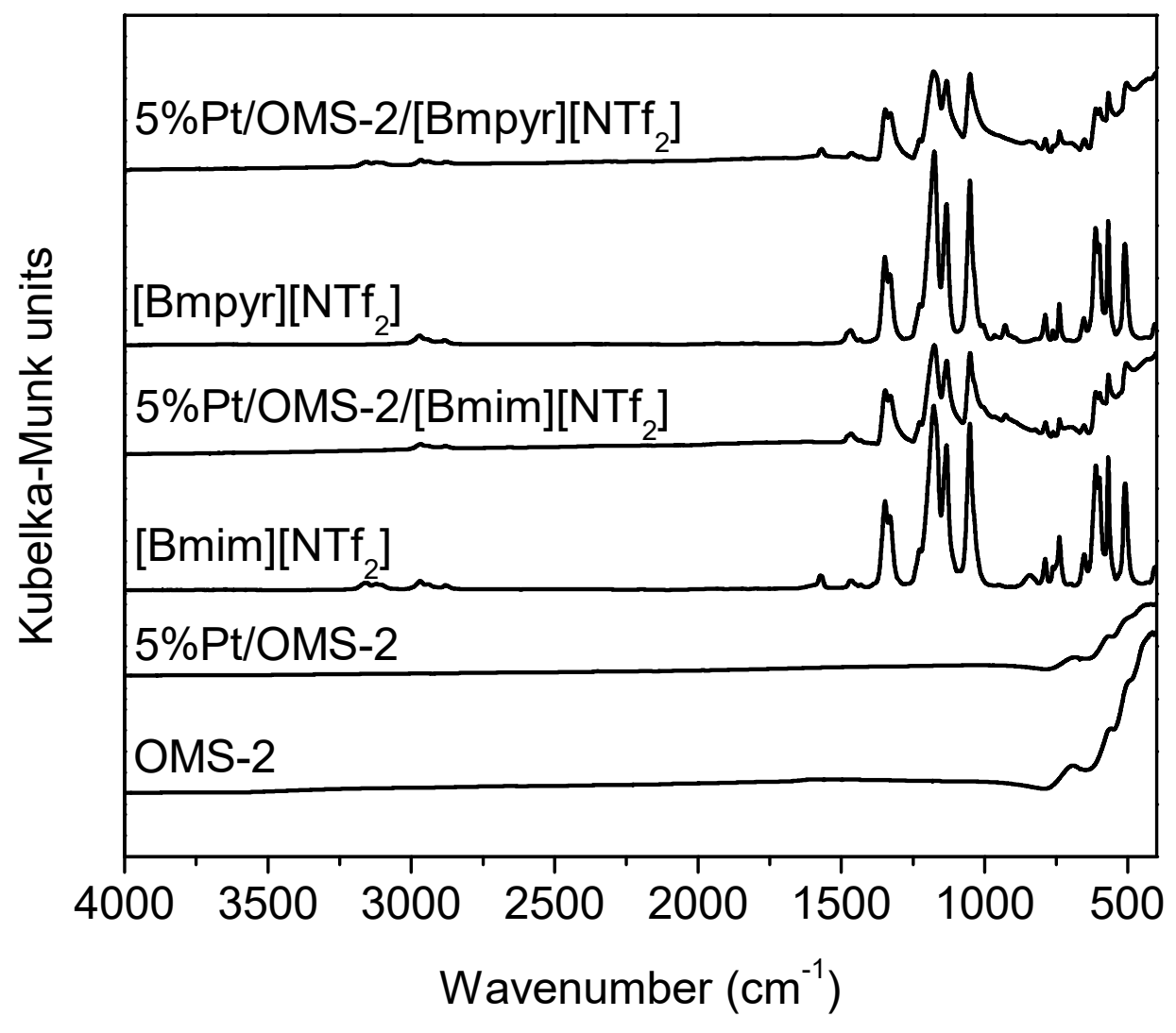

Figure 2. 


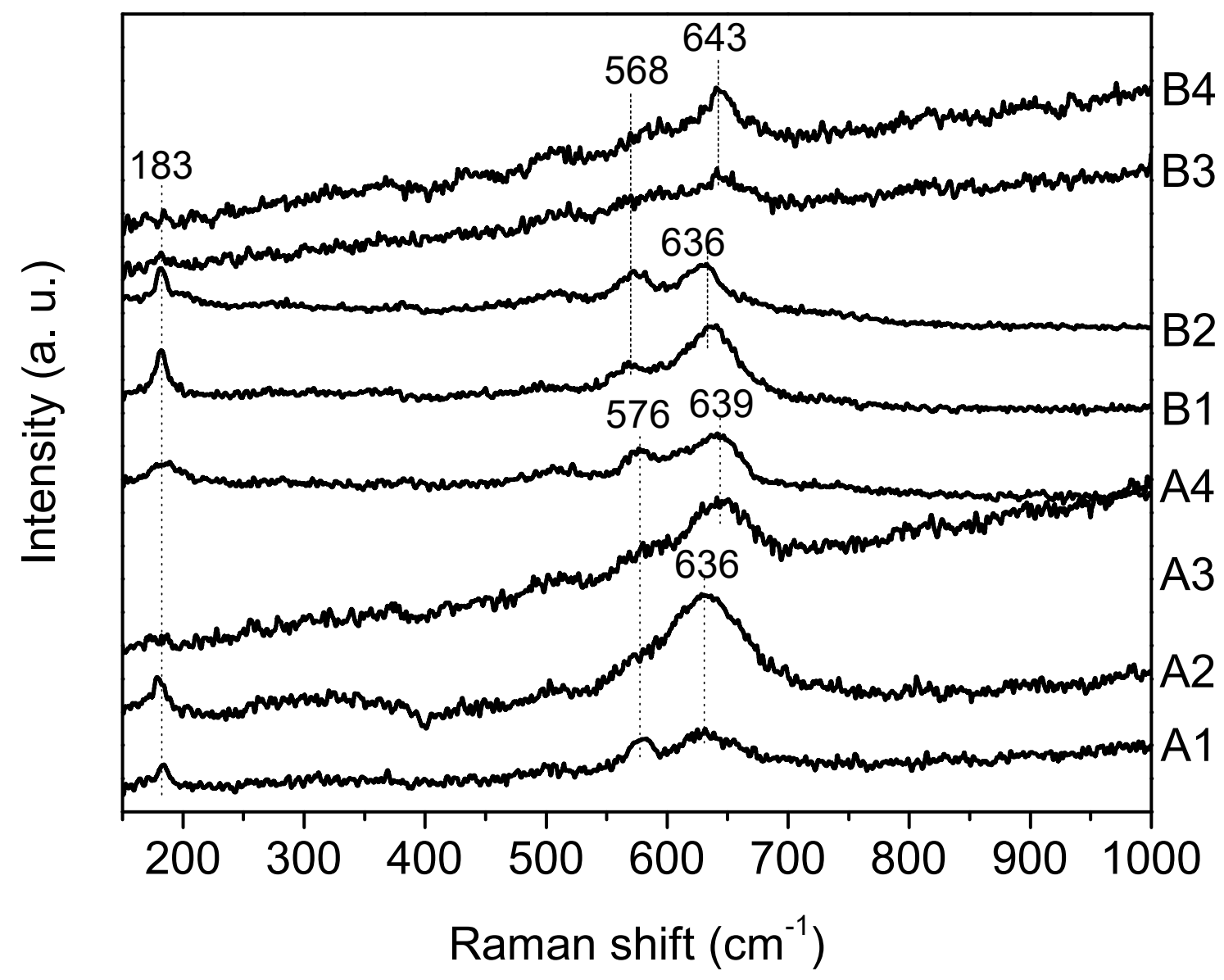

Figure 3. 

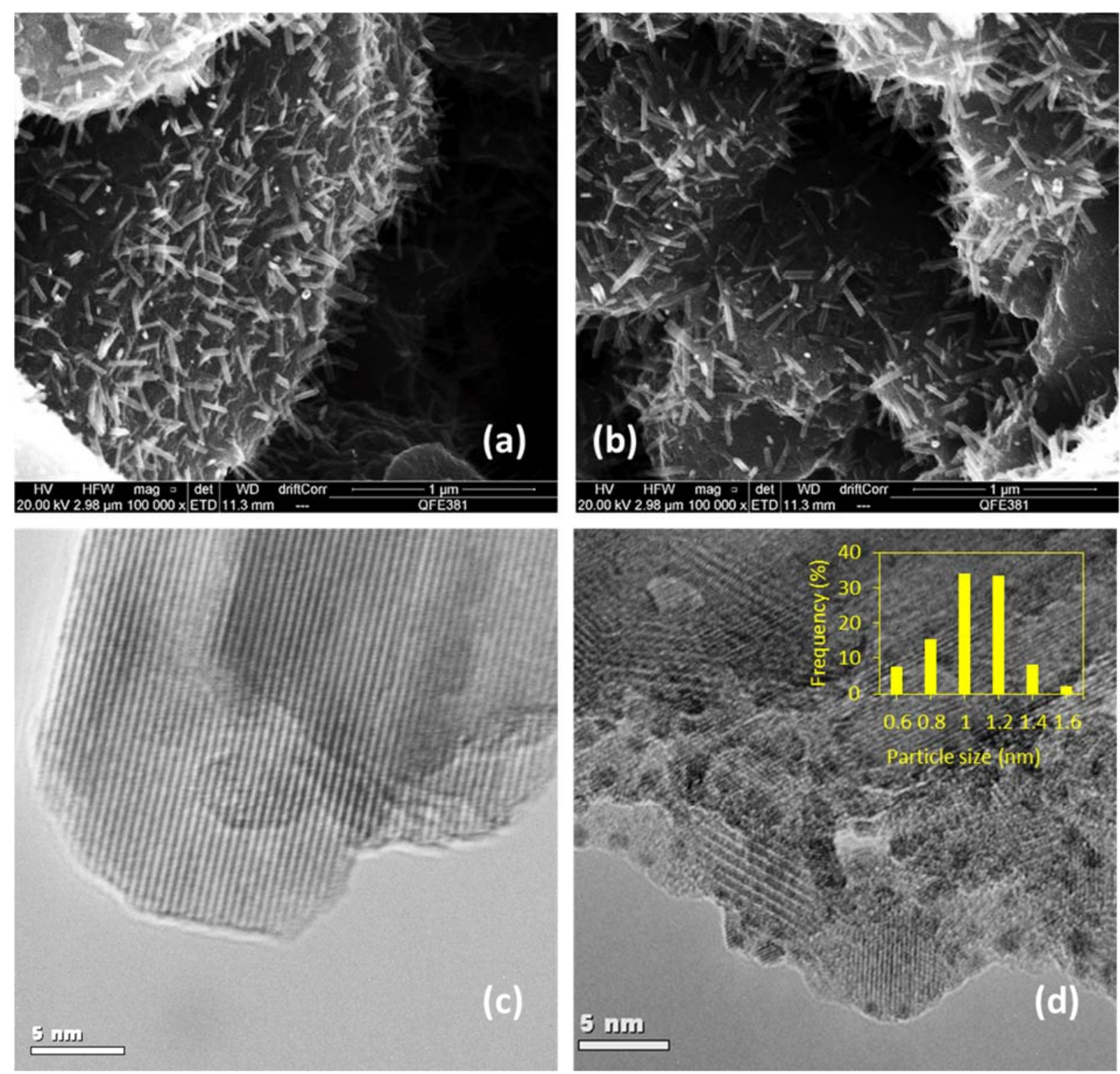

Figure 4. 


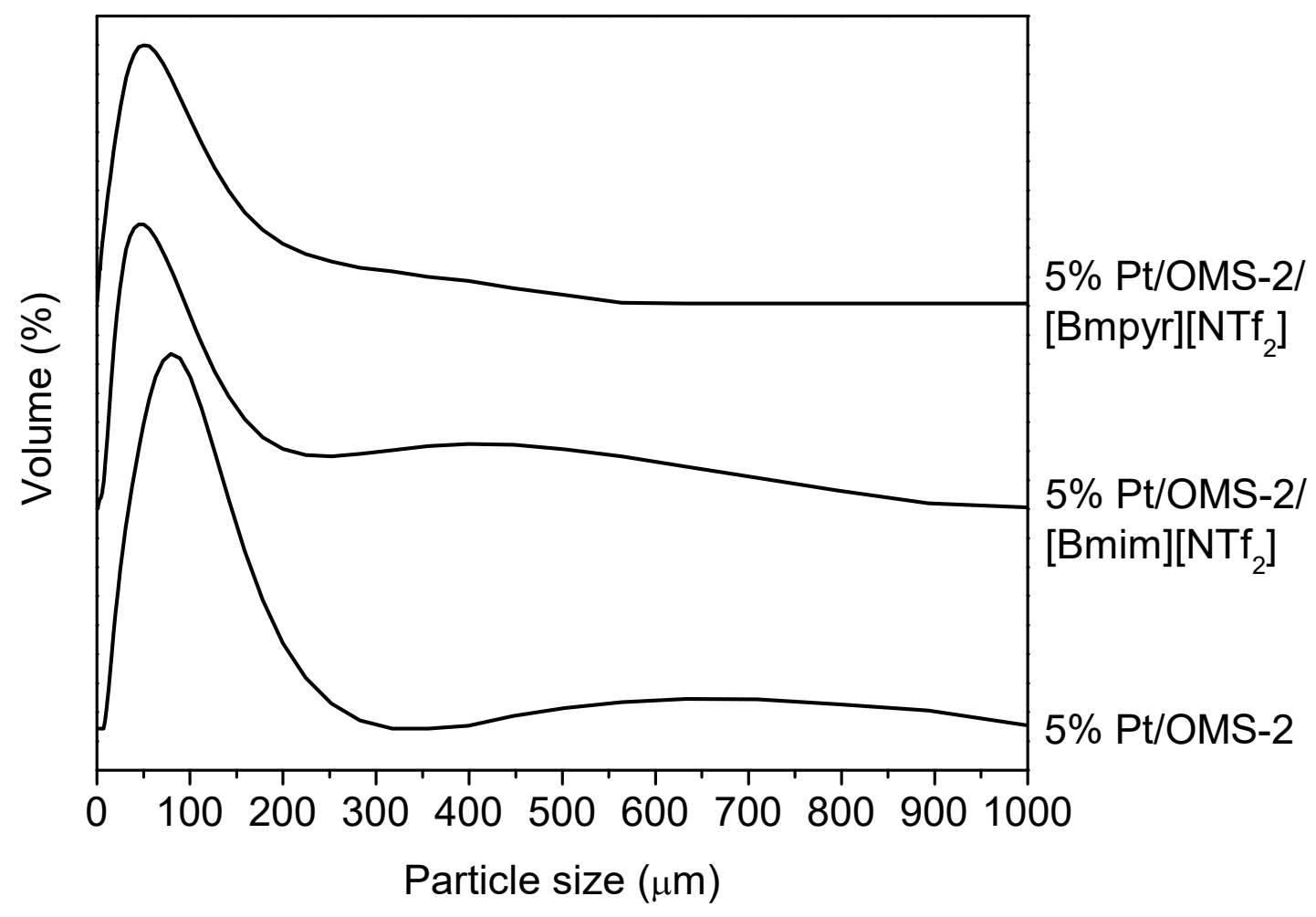

Figure 5. 

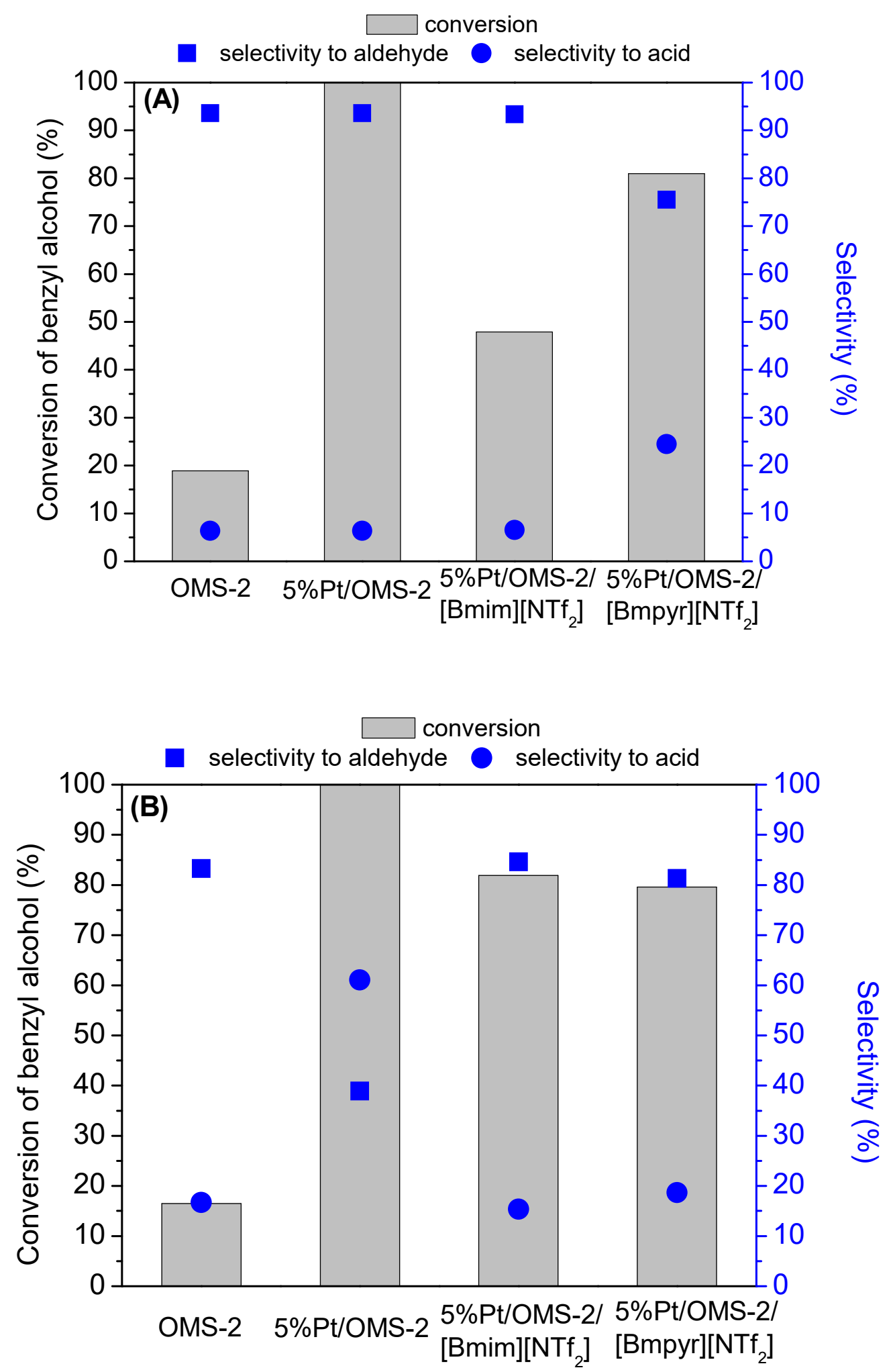

Figure 6. 
$5 \% \mathrm{Pt} / \mathrm{OMS}-2[\mathrm{Bmim}]\left[\mathrm{NTf}_{2}\right]$

Conv. alcohol

Sel. in aldehyde

Sel. in acid

5\% Pt/OMS-2 [Bmpyr] $\left.\mathrm{NTf}_{2}\right]$

Conv. alcohol

Sel. in aldehyde

$\bigcirc$ Sel. in acid

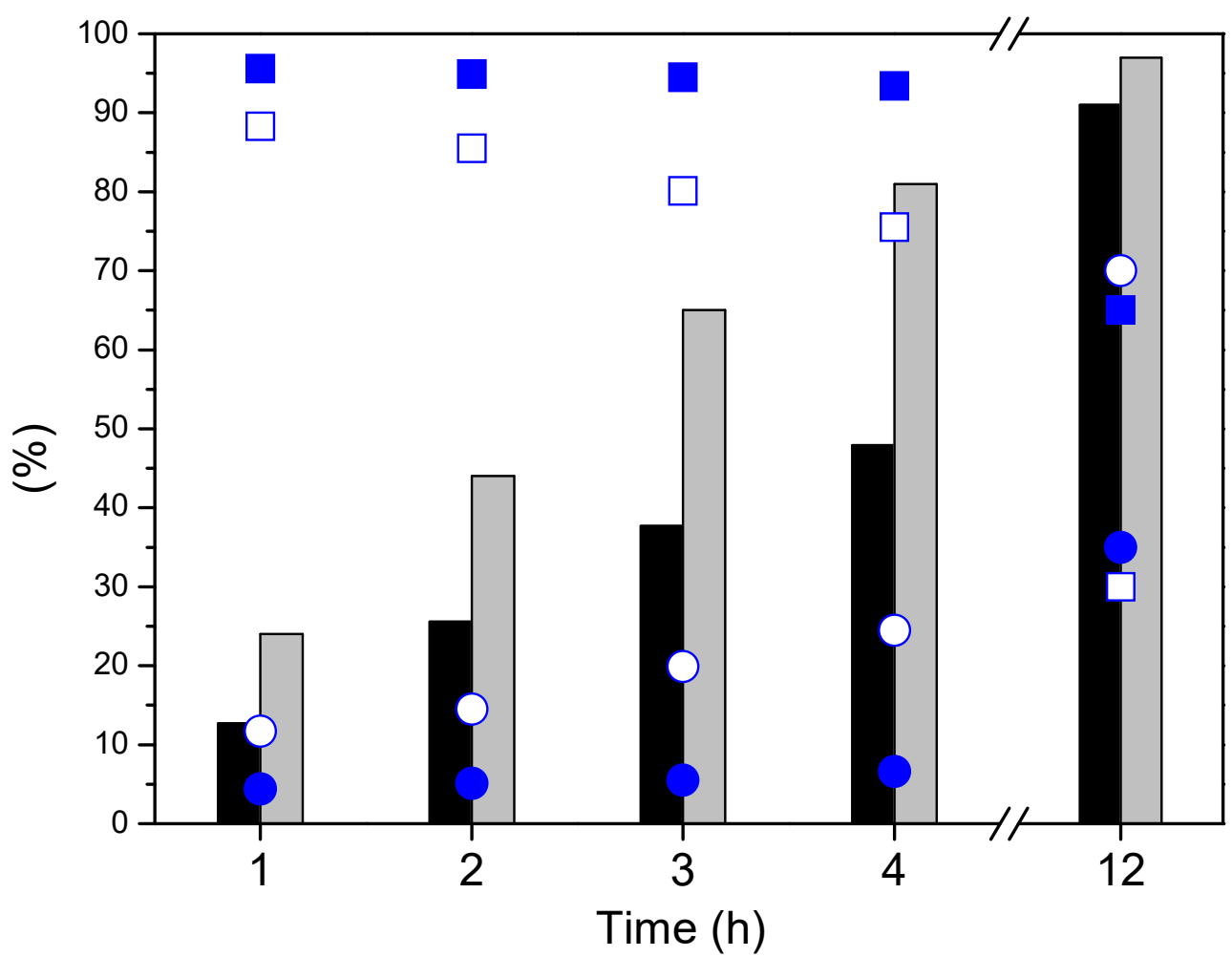

Figure 7. 
5\% Pt/OMS-2 / [Bmim][NTf $\left.{ }_{2}\right]$

Conv. alcohol - - - - Sel. aldehyde -

- Sel. acid

$5 \% \mathrm{Pt} / \mathrm{OMS}-2$ / [Bmpyr][ $\left.\mathrm{NTf}_{2}\right]$

Conv. alcohol - - $\square-$ - Sel. aldehyde - -O- - Sel. acid

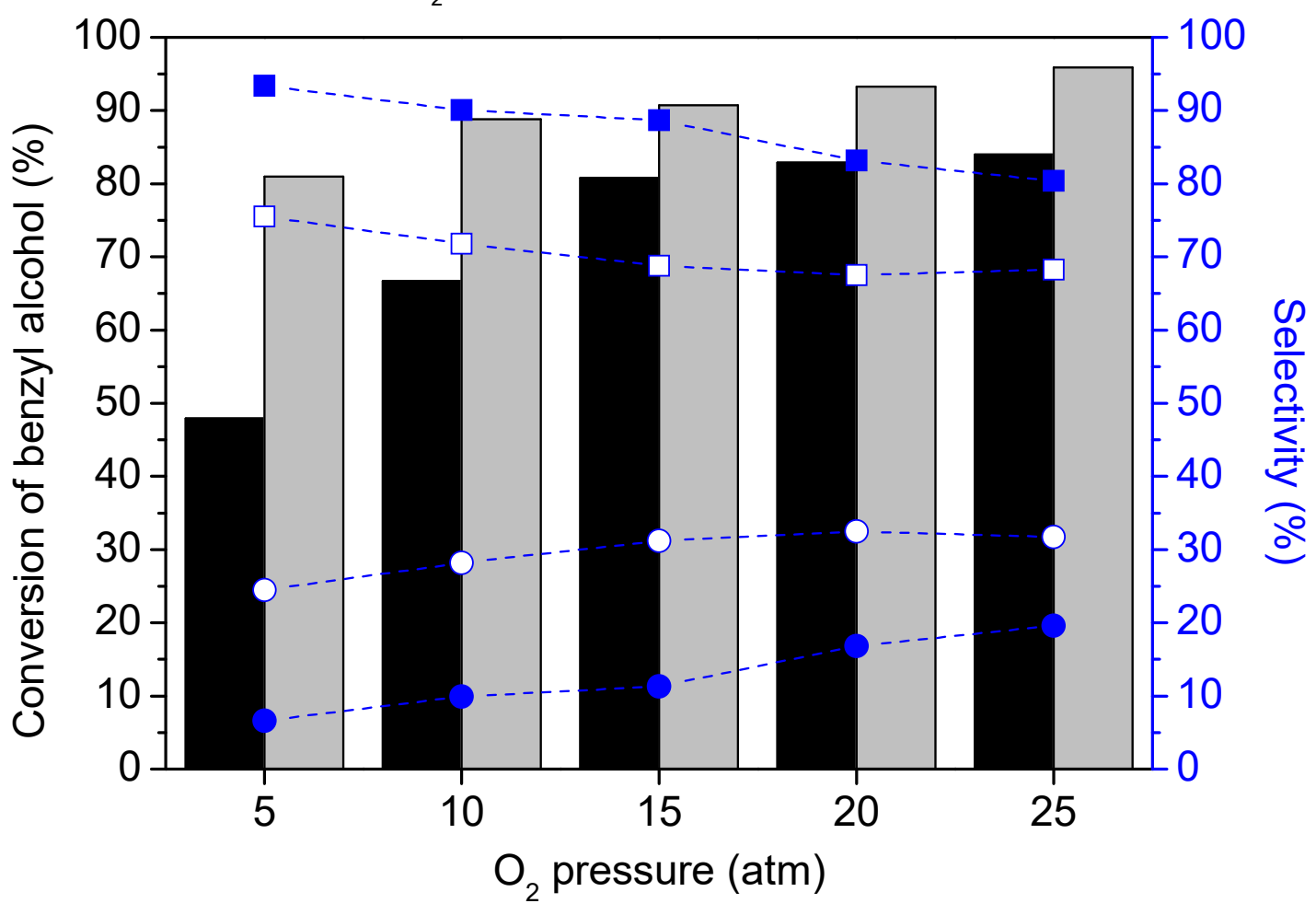

Figure 8. 

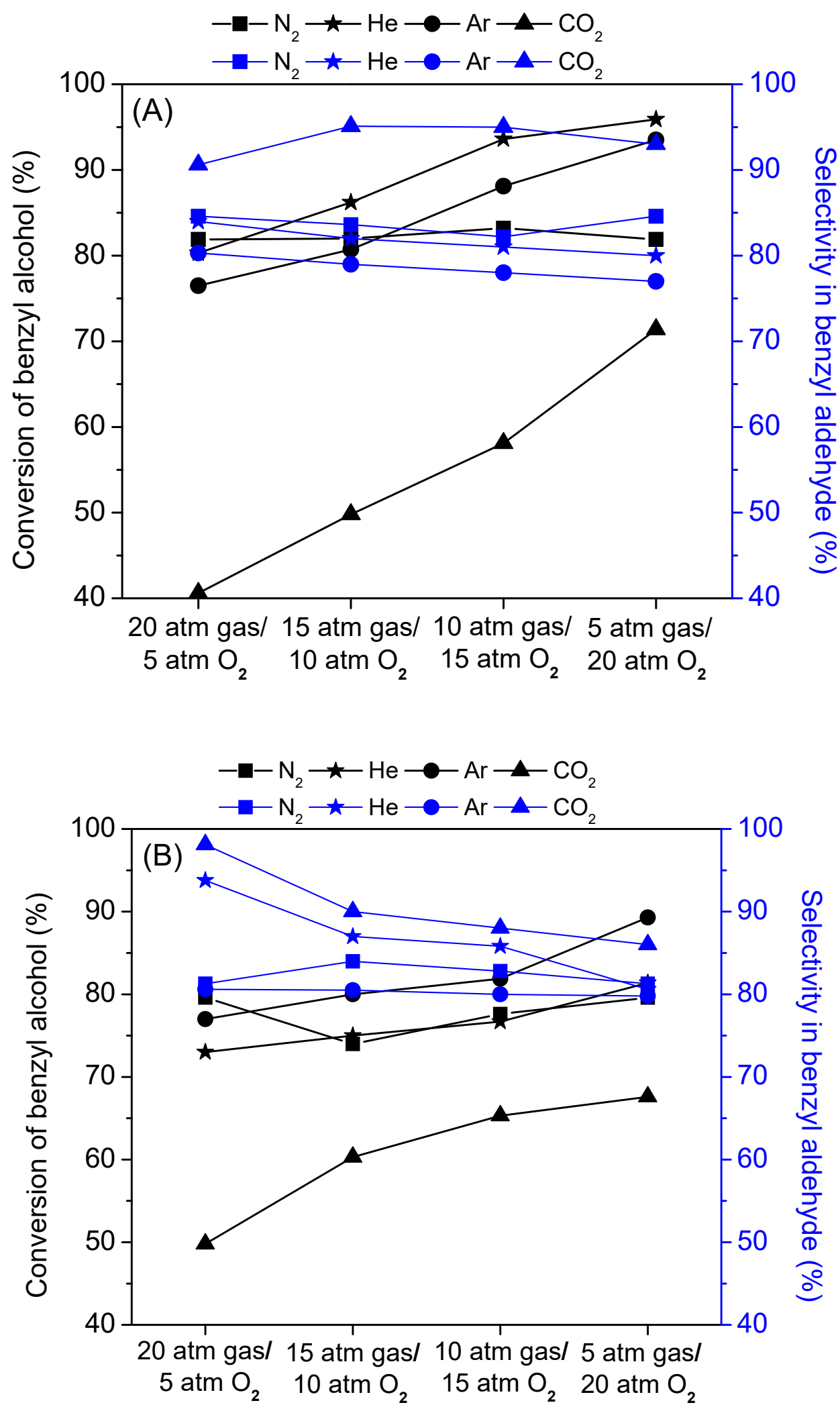

Figure 9. 